\title{
TWENTY-SEVEN YEARS OF BUTTERFLY OBSERVATIONS AT FISH BUTTE, ALBERTA
}

FELIX A. H. SPERLING, Department of Biology, University of Ottawa, Ottawa, Ontario. K1N 6N5

In 1966, my parents moved to a newly cleared farmsite on the south slope of Fish Butte, near Bragg Creek, Alberta. I enthusiastically launched myself into collecting and observing the wonderful diversity of skippers and butterflies on my doorstep. Between 1966 and 1992, I recorded 67 species of skippers and butterflies in an area of about 2 square $\mathrm{km}$ near my parents' farm. This is almost half of the butterfly fauna known for Alberta. I have summarized these records as a seasonal calendar (Table 1). I also point out some of the long-term faunal changes that have occurred during this time period, since these may relate to current issues in conservation and climate change.

Location and Habitats Fish Butte is located $26 \mathrm{~km}$ west of the southwestern corner of Calgary, at the southwestern corner of the Sarcee Indian Reserve $\left(50^{\circ} 55^{\prime} \mathrm{N}, 114^{\circ} 32^{\prime}\right.$ $W)$. It is a narrow ridge that thrusts perpendicularly northward into an old glacial outflow valley that now contains Fish Creek. The highest point of Fish Butte is at $1420 \mathrm{~m}$, and its north face drops abruptly to $1280 \mathrm{~m}$ in the valley bottom. The surface area of the highest part of the ridge is about 3 ha, and its south face slopes gently down to farmland.
The Fish Butte area contains an interesting juxtaposition of habitat types. The ridge itself is largely covered by a relatively open mixed forest of Aspen, Balsam Poplar, White Spruce and Lodgepole Pine. Its south slope is broken up by cutlines, roads and hayfields. There is a higher proportion of White Spruce and Balsam Poplar on its moister northern and eastern slopes. The northwestern slope of Fish Butte has a large grassy patch where the ridge is exposed to the full brunt of chinook winds. At the foot of the butte, the Fish Creek meanders through a willow and sedge swamp that is maintained by a population of beaver. There are patches of Swamp Birch (Betula glandifera) at the northwest foot of the butte, as well as in hummocky terrain located $2 \mathrm{~km}$ to the north-northeast. A small raised fen is located across the valley, 350 $\mathrm{m}$ northwest of the base of the butte. Although interspersed by several forms of wetlands, the south-facing slopes and mounds on the north side of the valley are covered primarily by prairie herbs and grasses. Cattle have grazed in this area for several decades.

Most skipper and butterfly species were commonly recorded along roads and cutlines or at the edge of 
clearings in mixed-wood areas. Two species, the Rustic Blue and Uhler's Arctic, were restricted to native grassland patches on the north side of the Fish Creek valley. The Giant Sulphur, Bog Fritillary and Jutta Arctic were restricted to wetlands with sedges, small willows and birches. The Frigga's Fritillary was restricted to the raised fen.

A similar assemblage of butterflies and habitats has been described from the Grave Flats campground $75 \mathrm{~km}$ to the south. ${ }^{2} A$ total of 61 species were found at this site, of which 52 are the same as at Fish Butte.

Identifications My records for 196668 were compiled from data labels on a small number of specimens. Starting in the spring of 1969 , I kept a daily record of all the species I encountered and I included collection data with every butterfly I collected. I continued to keep records throughout subsequent years and, by the end of 1974 , I had logged more than 550 days of observations. These were based on an hour or two of virtually every sunny day during weekends and the summer holidays, a half hour or more after I returned on the bus during school days, and regular commentary by my mother on the butterflies that had visited her garden each day. Between 1975-92, I added observations for 64 more days.

Common names generally follow Miller's recommendations. ${ }^{1}$ Scientific names are consistent with a planned book on the butterflies of Alberta, to be authored by G.J. Hilchie, N. Kondla, E.M. Pike and myself. Voucher specimens for most of the 67 species listed in Table 1 are deposited at the Canadian National Collection; the remainder are in my personal collection and consist mainly of papered material.
Four additional species may have been sighted at Fish Butte, but their identification is uncertain and no vouchers were collected. These include the Roadside Skipper (Amblyscirtes vialis; 26 June 1987), Lorquin' Admiral (Limenitis lorquini; 25 June 1987), Hydaspe Fritillary (Speyeria hydaspe; 24 July 1982) and the Variegated Fritillary (Euptoieta claudia; 21 August 1974).

Since the Fish Butte site contains elements of boreal, montane and prairie vegetational assemblages, it is not surprising that this is an area where butterfly species or races meet and hybridize to varying extents. I have studied hybrid interactions between the Anise and Old World Swallowtails at this site. ${ }^{3,4}$ Similar situations are probably also occurring here among the Sulphurs and the Electa and Atlantis Fritillaries.

Seasonal Patterns The highest seasonal diversity of butterflies occurs in June. All but 11 of 67 species have been found during this month.

Five species have two generations per year, including the Western White, Cabbage White, Clouded Sulphur, Purplish Copper and Painted Lady. Two of these, the Cabbage White and Clouded Sulphur, are the only species that feed primarily on agricultural crops during the larval stages.

Overwintered Anglewings, Tortoise Shells and Mourning Cloaks can be found flying until June, and the first fresh adults are out in early August. The Green Anglewing and Zephyr Anglewing are easily observed in the garden in the fall, sipping honeydew dropped by aphids feeding on Twining Honeysuckle. In the spring these two Anglewings are 
Table 1. Seasonal Occurrence of Butterflies at Fish Butte.

$X=$ common,$+=$ occasional or very local,.$=$ not observed, $?=$ precise date uncertain. Months are divided into 1-10th, 11-20th, and 21st-end.

Northern Cloudy Wing (Thorybes pylades)

Dreamy Dusky Wing (Erynnis icelus)

Persius Dusky Wing (Erynnis persius)

Arctic Skipper (Carterocephalus palaemon)

Garita Skipperling (Oarisma garita)

Draco Skipper (Polites draco)

Long Dash (Polites mystic)

Phoebus' Parnassian (Parnassius phoebus)

Canadian Tiger Swallowtail (Papilio canadensis)

Anise $X$ Old World Swallowtail (Papilio zelicaon X

Papilio machaon)

Western White (Pontia occidentalis)

Mustard White (Pieris napi)

Cabbage Butterfly (Pieris rapae)

Large Marble (Euchloe ausonides)

Northern Marble (Euchloe creusa)

Clouded Sulphur (Colias philodice)

Christina Sulphur (Colias christina)

Giant Sulphur (Colias gigantea)

Pink-edged Sulphur (Colias interior)

Bronze Copper (Hyllolycaena hyllus)

Purplish Copper (Epidemia helloides)

Reakirt's Copper (Epidemia mariposa)

Brown Elfin (Incisalia augustinus)

Hoary Elfin (Incisalia polia)

Western Pine Elfin (Incisalia eryphon)

Western Tailed Blue (Everes amyntula)

Spring Azure (Celastrina argiolus)

Silvery Blue (Glaucopsyche lygdamus)

Northern Blue (Lycaeides idas)

Greenish Blue (Plebejus saepiolus)

Rustic Blue (Agriades rusticus)

Edwards' Fritillary (Speyeria edwardsi)

Zerene Fritillary (Speyeria zerene)

Callippe Fritillary (Speyeria callippe)

\begin{tabular}{|c|c|c|c|c|c|c|}
\hline April & May & June & July & Aug & Sept & Oct \\
\hline$\ldots$ & ..t & $x X X$ & ++ & $\ldots$ & $\ldots$ & $\ldots$ \\
\hline$\ldots$ & ..t & $\ldots$ & $\ldots$ & $\ldots$ & $\ldots$ & $\ldots$ \\
\hline$\ldots$ &..+ & $X X X$ & ++ & $\ldots$ & $\ldots$ & $\ldots$ \\
\hline$\ldots$ &..+ & $+X X$ & $\cdots$ & $\ldots$ & $\ldots$ & $\ldots$ \\
\hline$\ldots$ & $\ldots$ & .? & $\ldots$ & $\ldots$ & $\ldots$ & $\ldots$ \\
\hline$\ldots$ & $\ldots$ & +++ & .t. & $\ldots$ & $\ldots$ & $\ldots$ \\
\hline$\ldots$ & $\ldots$ & $\ldots$ & .t. & $\ldots$ & $\ldots$ & $\ldots$ \\
\hline$\ldots$ & $\ldots$ & $\ldots$ & $\ldots$ & ?? & $\ldots$ & $\ldots$ \\
\hline$\ldots$ &..+ & $X X X$ & $X_{++}$ &..+ & $\ldots$ & $\ldots$ \\
\hline$\ldots$ & ..t & $X X X$ & $X_{++}$ & ++ . & $\ldots$ & $\ldots$ \\
\hline$\ldots$ & +++ &..+ & ..t & ..t & +++ & $\ldots$ \\
\hline$\ldots$ &..+ & .t+ &..+ & $\ldots$ & $\ldots$ & $\ldots$ \\
\hline$\ldots$ & $\ldots$ &..+ & $+x$ & $X X X$ & $X_{++}$ & $\ldots$ \\
\hline$\ldots$ & $\ldots$ & +++ & $\ldots$ & $\ldots$ & $\ldots$ & $\ldots$ \\
\hline$\ldots$ & ..t & .++ & $? .$. & $\ldots$ & $\ldots$ & $\ldots$ \\
\hline$\ldots$ & ..t & $X X+$ & t.t & $X X X$ & $X X_{+}$ & +++ \\
\hline$\ldots$ & $\ldots$ & .++ &.++ & $\ldots$ & $\ldots$ & $\ldots$ \\
\hline$\ldots$ & $\ldots$ & ..t & .t. & $\ldots$ & $\ldots$ & $\ldots$ \\
\hline$\ldots$ & $\ldots$ & ..t & $X X X$ & $X_{++}$ & .t. & $\ldots$ \\
\hline$\ldots$ & $\ldots$ & $\ldots$ & $\ldots$ &..+ & $\ldots$ & $\ldots$ \\
\hline$\ldots$ & $\ldots$ &..+ &.++ & . $+X$ & $x+$. & $\ldots$ \\
\hline$\ldots$ & $\ldots$ &..+ & $X X X$ & $X+$ & ++ & $\ldots$ \\
\hline ..t & $+X X$ & $X+$. &..+ & $\ldots$ & $\ldots$ & $\ldots$ \\
\hline$\ldots$ & $+X X$ & $X+$ & $\ldots$ & $\ldots$ & $\ldots$ & $\ldots$ \\
\hline$\ldots$ & $++X$ & $x_{+}$ &..+ & $\ldots$ & $\ldots$ & $\ldots$ \\
\hline$\ldots$ & ..t & $x \times x$ & $x+$. & $\ldots$ & $\ldots$ & $\ldots$ \\
\hline$\ldots$ &.++ &.++ & $\ldots$ & $\ldots$ & $\ldots$ & $\ldots$ \\
\hline$\ldots$ & $++X$ & $X X X$ & +++ & $\ldots$ & $\ldots$ & $\ldots$ \\
\hline$\ldots$ & $\ldots$ & ..t & ${ }_{+}^{+} X$ & $X_{++}$ & $\ldots$ & $\ldots$ \\
\hline$\ldots$ & $\ldots$ & ${ }_{+}^{+} \mathrm{X}$ & $X X X$ & ++ & $\ldots$ & $\ldots$ \\
\hline$\ldots$ & $\ldots$ & +++ &..+ & $\ldots$ & $\ldots$ & $\ldots$ \\
\hline$\ldots$ & $\ldots$ & ..t & +++ & $\ldots$ & $\ldots$ & $\ldots$ \\
\hline$\ldots$ & $\ldots$ &.++ & +++ & .t. & $\ldots$ & $\ldots$ \\
\hline$\ldots$ & $\ldots$ & ..t & +++ & $\ldots$ & $\ldots$ & $\ldots$ \\
\hline
\end{tabular}


Table 1. (continued)

\begin{tabular}{|c|c|c|c|c|c|c|c|}
\hline & April & May & June & July & Aug & Sept & Oct \\
\hline Atlantis Fritillary (Speyeria atlantis) & $\ldots$ & $\ldots$ &.+ &.$x X$ & +++ &..+ & $\ldots$ \\
\hline Electa Fritillary (Speyeria electa) & $\ldots$ & $\ldots$ &..$x$ & $X X X$ & $X_{++}$ & $\cdots$ & $\ldots$ \\
\hline Mormon Fritillary (Speyeria mormonia) & $\ldots$ & $\ldots$ &..+ & $+X X$ & ++ &.+ & \\
\hline Bog Fritillary (Boloria eunomia) & $\cdots$ & $\ldots$ & $+x$ & ++ & $\ldots$ & $\cdots$ & $\cdots$ \\
\hline Silver-bordered Fritillary (Boloria selene) & $\ldots$ & $\ldots$ & $\ldots$ & t+ &..+ & $\ldots$ & $\ldots$ \\
\hline Meadow Fritillary (Boloria bellona) & $\ldots$ & ..t & $+X_{+}$ & $\ldots$ & $\cdots$ & $\ldots$ & $\ldots$ \\
\hline Frigga's Fritillary (Boloria frigga) & $\ldots$ & $\ldots$ & +. &..+ & $\ldots$ & $\ldots$ & $\cdots$ \\
\hline Freija Fritillary (Boloria freija) & ..+ & $+X X$ & $x X_{+}$ & $\ldots$ & $\ldots$ & $\ldots$ & $\ldots$ \\
\hline Titania Fritillary (Boloria titania) & $\cdots$ & $\ldots$ &.++ & $+X X$ & $x \times x$ & +++ & $\ldots$ \\
\hline Northern Checkerspot (Chlosyne palla) & $\ldots$ & $\ldots$ & $\cdots$ & +++ &..+ & $\ldots$ & $\cdots$ \\
\hline Field Crescent (Phyciodes pratensis) & $\cdots$ & $\cdots$ & ++ & +++ & $\cdots$ & $\cdots$ & $\cdots$ \\
\hline Tawny Crescent (Phyciodes batesii) & $\cdots$ & $\cdots$ & ..t &.++ & $\ldots$ & $\ldots$ & $\ldots$ \\
\hline Morpheus Crescent (Phyciodes morpheus) & $\cdots$ & $\ldots$ & $++X$ & $x X_{+}$ & $\ldots$ & $\ldots$ & $\ldots$ \\
\hline Satyr Anglewing (Polygonia satyrus) &.++ &.++ &..+ & $\ldots$ &.++ & ++ &..+ \\
\hline Green Anglewing (Polygonia faunus) & $\ldots$ & +++ & $\cdots$ & $\ldots$ & $+x X$ & $x X_{+}$ &.++ \\
\hline Zephyr Anglewing (Polygonia zephyrus) & $\cdots$ & $\ldots$ & t.t & $\cdots$ & $+x$ & $x++$ & $\ldots$ \\
\hline Gray Anglewing (Polygonia progne) & ++ & $x X X$ & $x X_{+}$ &..+ &.++ & $X+$ &.+ \\
\hline Mourning Cloak (Nymphalis antiopa) & $+\mathrm{X}$ & $x x x$ & $x+$ & $\ldots$ & $+x X$ & $x \times x$ & $X+$. \\
\hline Compton Tortoise Shell (N. vaualbum) & $\cdots$ & $\ldots$ & $\cdots$ & $\cdots$ & $\cdots$ & +++ &.+ \\
\hline California Tortoise Shell ( $N$. californica) & $\cdots$ & $\cdots$ & ++ & $\cdots$ & $\cdots$ &.++ & $\cdots$ \\
\hline Milbert's Tortoise Shell (Aglais milberti) &.$X X$ & $x X X$ & $X .+$ & +++ & $+X X$ & $x X X$ & $X_{++}$ \\
\hline Painted Lady (Vanessa cardui) & &.$x x$ & $x x x$ & $\mathrm{XXX}$ & $x x x$ & $x \times x$ & $\ldots$ \\
\hline West Coast Lady (Vanessa anabella) & $\cdots$ & $\cdots$ & $\cdots$ & $\cdots$ & $\cdots$ & $\cdots$ &..+ \\
\hline Red Admiral (Vanessa atalanta) & $\cdots$ & ..+ & +++ & $\cdots$ &.+ &..+ & $\cdots$ \\
\hline White Admiral (Limenitis arthemis) & $\cdots$ & $\cdots$ &.++ & $x x x$ & $x_{++}$ & $\cdots$ & $\cdots$ \\
\hline Inornate Ringlet (Ceononympha inornata) & $\ldots$ & $\cdots$ &.++ & $x \times x$ & ++ & $\cdots$ & $\ldots$ \\
\hline Dark Wood Nymph (Cercyonis oetus) & $\cdots$ & $\cdots$ & $\ldots$ &.++ & ++ & $\ldots$ & $\ldots$ \\
\hline Common Wood Nymph (Cercyonis pegala) & $\cdots$ & $\ldots$ & $\ldots$ & $\ldots$ & +++ &..+ & $\cdots$ \\
\hline Red-disked Alpine (Erebia discoidalis) & &.$x x$ & ++ & $\ldots$ & $\cdots$ & $\ldots$ & $\cdots$ \\
\hline Common Alpine (Erebia epipsodia) & $\ldots$ & $\cdots$ & $+x x$ & $x X_{+}$ & .. & $\cdots$ & $\ldots$ \\
\hline Macoun's Arctic (Oeneis macounii) & $\ldots$ & $\cdots$ & $+X X$ & $X_{++}$ & $\cdots$ & $\cdots$ & $\ldots$ \\
\hline Uhler's Arctic (Oeneis uhleri) & & + & $\cdots$ & $\cdots$ & $\cdots$ & $\ldots$ & $\ldots$ \\
\hline Jutta Arctic (Oeneis jutta) & $\cdots$ & $\cdots$ & .+. & $\cdots$ & $\cdots$ & $\cdots$ & $\ldots$ \\
\hline
\end{tabular}


much less commonly observed. The Red Admiral probably also overwinters as an adult.

Yearly Changes in Abundance At least one species, the Macoun's Arctic, has a biennial life cycle. Macoun's Arctics were numerous in 1970 but, since then, there have been much larger numbers of adults flying during odd years than even years. It is a mystery why the evenyear cohort remains small, even though a few adults continue to emerge during those years.

Some species are occasional migrants. A few California Tortoise Shells were observed in 1973, 1974 and 1987, and only a single West Coast Lady was ever found, in 1969. The Painted Lady is certainly a migrant; large numbers were collected throughout the summer of 1973 and I have other records from 1966, 1983 and 1992. It is unclear whether populations of the Red Admiral are replenished by migrations.

Other species may undergo occasional dispersal on a smaller scale. One male and one female Phoebus' Parnassian were caught on separate days in August 1968 as they flew eastward across the farmyard. Both were heading toward the prairies, having flown about $15 \mathrm{~km}$ east of their normal habitat in the mountains. I never saw the species again at Fish Butte in subsequent years.

A number of skippers and butterflies were observed only sporadically, but their apparent rarity is probably a reflection of the fact that they are near the edge of their normal habitat range. The most obvious examples include the Garita Skipperling, Long Dash, Bronze Copper, Frigga's Fritillary, and Jutta's Arctic. In 1974 I recorded four Jutta's
Arctics at the northeast base of Fish Butte, along a cutline lined with sedges, White Spruce and River Birch (Betula occidentalis), but I was unable to find any individuals there in subsequent years.

Some species are well within their normal habitat range, but seem to have large populations for only a couple of years, after which they are apparently absent. The Northern Checkerspot presents the most obvious case. I found one individual in 1969 and two in 1971. In 1972 the species was common throughout July. In subsequent years I never found a single one; the population seemed to have boomed and bust in just three years. Edward's Fritillary may be a similar case. I found a number of individuals in 1967 and then again in 1972, 1973 and 1974. Since then, I have observed only a single individual, in 1987.

A more perplexing situation is presented by several species that were common over several years but have now declined greatly in numbers. The Mustard White, Purplish Copper, Northern Blue, Field Crescent, and Zerene Fritillary were all frequently encountered in the early 1970s, but have not been recorded since 1974 , for the Mustard White, or 1976, for the remaining four species. The apparent decline of Purplish Coppers may be due to increased haying around the farmyard, which would have reduced the amount of dock (Rumex sp.) available for larval foodplant. The other species are not so easily accounted for, since they occurred in undisturbed habitats. Their decline coincides with an increased drying out of habitats on all slopes of Fish Butte and the disappearance of many patches of Ground Pine (Lycopodium obscurum), a plant of moist boreal woods. 
Possible causes include decreased winter snow cover and recent construction of new roads and cutlines.

It seems likely that the relatively high diversity of the Fish Butte site is due to its location at the boundary between montane, prairie and boreal habitat zones. Given the possibility that widespread global warming may now be occurring, it will be especially interesting to document changes in the community of skippers and butterflies at Fish Butte over the next few decades.

Acknowledgements I thank C.D. Bird for help with identifications when I was starting out, and my parents, Gudrun and Werner Sperling, for encouragement.
1. MILLER, J.Y. 1992. The common names of North American butterflies. Smithsonian Institution Press, Washington.

2. PINEL, H.W. 1983. Skippers and butterflies of the Indian Grave campground area, Alberta. Blue Jay 41: 71-77.

3. SPERLING, F.A.H. 1987. Evolution of the Papilio machaon species group in western Canada. Quaestiones Entomologicae 23: 198-315.

4. SPERLING, F.A.H. and N.G. KONDLA. 1991. Alberta swallowtails and parnassians: natural history, keys, and distribution. Blue Jay 49: 183-92.

The birds of the air are my brothers, All flowers are my sisters,

The trees are my friends.

All living creatures, mountains and streams, I take unto my care.

For this green earth is our mother, Hidden in the sky is the Spirit above.

I share one life with all who are here;

To everyone I give my love,

To everyone I give my love.

Joseph Cornell, 1987. Listening to Nature, Dawn Publications. 